\title{
FAKTOR PRODUKSI DAN PERKEMBANGAN PRODUKSI USAHA BUDIDAYA RUMPUT LAUT KOTONI DI KABUPATEN SERAM BAGIAN BARAT
}

\section{Production Factors And Development Of The Cottoni Seaweed Cultivation In Western Seram Regency}

\author{
*Robert Pensa Maryunus ${ }^{1}$, Johanes Hiariey ${ }^{2}$ dan Yoisye Lopulalan ${ }^{2}$ \\ ${ }^{1}$ UPTD Balai Budidaya Laut Tual, Dinas Kelautan dan Perikanan Provinsi Maluku \\ JIn. Taar Baru Kota Tual, Maluku, Indonesia \\ ${ }^{2}$ Fakultas Perikanan dan IImu Kelautan Universitas Pattimura \\ Jln. Mr. Chr. Soplanit, Desa Poka, Ambon, Maluku, Indonesia \\ Diterima tanggal: 12 September 2018 Diterima setelah perbaikan: 29 Oktober 2018 \\ Disetujui terbit: 17 Desember 2018 \\ *email: roby_pm@yahoo.co.id
}

\begin{abstract}
ABSTRAK
Budidaya rumput laut kotoni merupakan komoditas unggulan Kabupaten Seram Bagian Barat yang mendapat atensi pemerintah dalam pengembangannya. Penelitian ini bertujuan untuk mengkaji faktor-faktor produksi dan perkembangan produksi usaha budidaya rumput laut di Kabupaten Seram Bagian Barat. Analisis dilakukan dengan metode deskriktif kuantitatif dan kualitatif. Hasil kajian faktorfaktor produksi menunjukkan lahan yang dinyatakan layak bagi usaha budidaya rumput laut tingkat pemanfaatannya masih sangat rendah. Material dan sarana penunjang serta bibit tersedia dan cukup mudah diperoleh. Sumberdaya manusia pembudidaya tersedia dan dengan dominasi tingkat pendidikan yang relatif rendah yakni sekolah dasar. Hasil kajian perkembangan volume produksi menunjukkan trend penurunan sejak tahun 2009. Kualitas produksi rumput laut kering yang dihasilkan pembudidaya secara umum mutunya masih rendah dan belum sesuai dengan spesifikasi pabrikan dan eksportir. Untuk pengembangan usaha dibutuhkan ekstensifikasi lahan, pembinaan mutu produk serta upaya menstabilkan harga jual rumput laut kering.
\end{abstract}

Kata Kunci: faktor produksi; perkembangan produksi; budidaya rumput laut; Seram Bagian Barat

\begin{abstract}
The cultivation of cottoni seaweed is priority commodity of Western Ceram Regency which gets attention by government in its development. This study was aimed to examine the factors of production and development of red seaweed cultivation production business in West Ceram District. The analysis is done by quantitative and qualitative descriptive methods. Result of the study on factors of production shows that suitable land for red seaweed cultivation utilization is still very low. Supporting materials and facilities and also seeds are available and easily accessible. Human resources of farmers are available; however, a relatively low level of education at background with dominantly primary schools. While the results of the study of the development of production volume shows a decreased trend since 2009 , in general the quality of dried seaweed production produced by farmers is still low and it is not in accordance with the specifications of manufacturers and exporters. For business development, it requires land extensification, coaches of increase product quality and efforts to stabilize price.
\end{abstract}

Keywords: production factors; production development; seaweed cultivation; Western Seram

\section{PENDAHULUAN}

Pemerintah Kabupaten Seram Bagian Barat (SBB) dalam kebijakan pembangunannya telah menempatkan komoditas rumput laut kotoni sebagai komoditas unggulan untuk dikembangkan dengan pertimbangan luas wilayah potensial bagi pengembangan komoditas ini masih cukup tersedia (Bappeda Kabupaten SBB, 2011). Salah satu permasalahan utama usaha budi daya rumput laut di Kabupaten SBB adalah belum tersedianya kajian informasi terkait faktor-faktor produksi dan perkembangan produksi yang bisa dijadikan landasan dalam perencanaan dan pengambilan kebijakan pengembangan usaha. 
Keterkaitan antara faktor produksi dan perkembangan volume produksi sangat erat dimana tinggi rendahnya volume produksi sangat ditentukan oleh sejauh mana efektifitas dan efisiensi pemanfaatan faktor-faktor produksi itu sendiri. Penelitian ini bertujuan mengkaji faktorfaktor produksi (lahan, sarana dan tenaga kerja) serta perkembangan volume produksi usaha budi daya rumput laut di Kabupaten Seram Bagian Barat. Hasilnya diharapkan menjadi salah satu masukan bagi pengembangan usaha budi daya rumput laut di Kabupaten SBB.

\section{METODOLOGI}

\section{Lokasi dan Waktu Penelitian}

Lokasi penelitian dilakukan pada 2 (dua) kecamatan yang menjadi sentra budi daya rumput laut Kabupaten Seram Bagian Barat, secara rinci ditampilkan pada Tabel 1. Penelitian ini berlangsung dari bulan April sampai dengan September 2011.

\section{Jenis dan Sumber Data}

Jenis data yang dikumpulkan bersumber dari data primer dan data sekunder. Data primer meliputi: lahan, sarana dan tenaga kerja diperoleh melalui kuisioner, wawancara dan observasi langsung dari sumber pertama. Sedangkan data sekunder yakni perkembangan volume produksi diperoleh melalui penelusuran ke lembaga terkait yakni Dinas Kelautan dan Perikanan Kabupaten Seram Bagian Barat.

\section{Metode Pengumpulan Data}

Penelitian ini menggunakan metode survei deskriptif (the descriptive survey method). Metode deskriptif adalah metode penelitian yang berusaha mendeskripsikan atau menggambarkan serta melukiskan fenomena atau hubungan antara fenomena yang diteliti secara sistematis, aktual dan akurat (Arikunto, 2002). Keseluruhan tahapan penelitian mulai persiapan, pengumpulan data, pengolahan dan analisis data dilakukan dengan prinsip pendekatan kuantitatif dan kualitatif (Creswell, 1994).

Pemilihan lokasi dusun/negeri dilakukan secara purposive (Sugiyono, 2009), dengan pertimbangan lokasi tersebut eksis melakukan kegiatan budi daya pada saat pelaksanaan penelitian. Pemilihan responden pembudidaya dilakukan berdasarkan teknik cluster random sampling (Sugiyono, 2009), dengan pertimbangan, Pertama, sub populasi pembudidaya tersebar pada lokasi-lokasi tertentu pada area yang luas dengan distribusi jumlah yang tidak seimbang; Kedua, interval jumlah kepemilikan tali bentangan yang menjadi indikator luas lahan pembudidaya berbeda-beda dan tidak terwakili pada semua sub populasi.

Jumlah pembudidaya yang eksis berdasarkan informasi dari masing-masing kepala dusun setempat berjumlah total 322 pembudidaya. Jumlah sampel pembudidaya (unit usaha) ditetapkan kurang lebih $15 \%$ dari populasi total (Arikunto, 2002), dengan mempertimbangkan jumlah dari populasi pembudidaya yang eksis pada masing-masing lokasi penelitian. Jumlah unit usaha yang diambil sebagai sampel pada masingmasing lokasi penelitian sebanyak 53 unit usaha masing-masing: Pulau Osi 10 unit usaha, Loun 5 unit usaha, Kotania 10 unit usaha, Wael 15 unit usaha, Taman Jaya 5 unit usaha, Airpesi 5 unit usaha dan Nuruwe Nuruwe 3 unit usaha.

\section{Metode Analisis Data}

\section{a) Faktor-Faktor Produksi}

Analisis faktor-faktor produksi dilakukan secara deskriptif berdasarkan observasi, kuisioner dan wawancara dengan pembudidaya dan pemangku kepentingan yang memahami usaha rumput laut.

Tabel 1. Lokasi Penelitian.

Table 1. Research Location.

\begin{tabular}{cccc}
\hline No & Kecamatan/ Sub-district & Desa (Negeri)/Village & Dusun/Sub-village \\
\hline 1. & Seram Barat & Desa Eti & Pulau Osi \\
& & : Kotania \\
& & Loun \\
& & Desa Piru & Wael \\
& & & A Airpessi \\
& & & Taman Jaya \\
& Kairatu Barat & Nuruwe & Nuruwe \\
\hline
\end{tabular}




\section{b) Perkembangan Produksi}

Perkembangan volume produksi dianalisis secara deskriptif kuantitatif berdasarkan data time series perkembangan volume produksi rumput laut selama 5 tahun (2006 - 2010), diperoleh dari instansi terkait yakni Dinas Kelautan dan Perikanan Kabupaten Seram Bagian Barat. Diversifikasi dan mutu produk dianalisis secara deskriptif kualitatif berdasarkan observasi di lapangan dan wawancara dengan pemangku kepentingan seperti Dinas Kelautan dan Perikanan Kabupaten Seram Bagian Barat serta pelaku-pelaku pemasaran.

\section{HASIL DAN PEMBAHASAN}

\section{Faktor-Faktor Produksi}

Pada usaha budi daya rumput laut faktorfaktor produksi yang berperan adalah lahan, sarana (material dan sarana penunjang; bibit) dan tenaga kerja. Faktor-faktor produksi adalah sumberdaya yang digunakan dalam sebuah proses produksi barang dan jasa (Wikipedia, 2011).

\section{a. Lahan}

Luas lahan eksisting dan jumlah unit usaha pada saat dilakukan penelitian tersaji pada Tabel 2. Pada Tabel 2 terlihat bahwa jumlah unit usaha yang terbanyak terdapat di Dusun Wael sebanyak 132 unit dengan luas lahan total 70,62 Ha sedangkan unit usaha yang paling sedikit terdapat di Dusun Loun dan sebanyak 8 unit dengan luas lahan 4,32 Ha.
Berdasarkan data per bulan Agustus 2011 pada Tabel 2 terlihat bahwa total unit usaha yang eksis beroperasi sebanyak 332 unit dengan total luas lahan eksisting seluas $157,10 \mathrm{Ha}$ dengan rata-rata luas kepemilikan lahan seluas 0,58 $\mathrm{Ha}$. Berdasarkan rata-rata luas kepemilikan lahan usaha skala budi daya rumput laut di Kabupaten SBB tergolong kedalam usaha mikro (Peraturan Menteri KP No. 5 Tahun 2009). Dusun Wael merupakan sentra produksi utama rumput laut di Kabupaten SBB sedangkan Dusun Loun merupakan dusun yang relatif masih baru dalam usaha budi daya rumput laut. Secara keseluruhan unit usaha rumput laut terdapat pada dua Kecamatan yakni Kecamatan Seram Barat masing-masing di dua desa yakni Desa Eti dan Desa Piru dan di Kecamatan Kairatu Barat yakni Negeri Nuruwe.

Hasil pengamatan di lapangan menunjukkan bahwa jumlah kepemilikan tali bentangan yang diusahakan responden pembudidaya bervariasi antara 10 bal - 70 bal. Banyak sedikitnya jumlah bentangan tali bentangan yang diusahakan pembudidaya menunjukkan besar kecilnya skala usaha budi daya rumput laut. Perbedaan skala usaha tersebut akan berimplikasi pada perbedaan produksi dan produktivitas pembudidaya, namun tidak menutup kemungkinan skala usaha yang lebih kecil akan memiliki produksi dan produktivitas yang tinggi bila dikelola secara efisien. Menurut Soekartawi (2002) bahwa luas lahan pertanian (dalam hal ini lahan budi daya rumput laut) akan mempengaruhi skala usaha dan efisien tidaknya suatu usaha pertanian. Lahan merupakan salah

Tabel 2. Jumlah Unit Usaha, Luas Lahan Eksisting dan Rataan Luas Lahan Usaha Budi Daya Rumput Laut Kotoni di Kabupaten Seram Bagian Barat, Agustus 2011.

Table 2. Number Of Business Units, Existing And Average Areas Of Cottoni Seaweed Cultivation In Western Seram Regency, August 2011.

\begin{tabular}{lccc}
\hline \multicolumn{1}{c}{ Lokasi/Location } & $\begin{array}{c}\text { Jumlah Unit Usaha } \\
\text { Budidaya/ Amount of } \\
\text { Business Unit (KK) }\end{array}$ & $\begin{array}{c}\text { Luas Lahan Eksisting/ } \\
\text { Existing Area (Ha) }\end{array}$ & $\begin{array}{c}\text { Rataan Luas Lahan/ } \\
\text { Average of Area (Ha) }\end{array}$ \\
\hline Desa Eti/ Eti Village & 54 & 25.41 & 0.47 \\
$\quad$ Pulau Osi & 58 & 22.10 & 0.38 \\
Kotania & 8 & 4.32 & 0.54 \\
$\quad$ Loun & 132 & & 0.54 \\
Desa Piru/ Piru Village & 30 & 70.62 & 0.38 \\
$\quad$ Wael & 30 & 11.25 & 0.37 \\
$\quad$ Airpessi & 10 & 10.98 & 1.42 \\
$\quad$ Taman Jaya & 332 & 14.17 & $\mathbf{0 . 5 8}$ \\
Negeri Nuruwe/ Nuruwe Village & & $\mathbf{1 5 8 . 8 4}$ & \\
$\quad$ Nuruwe & & & \\
\hline Jumlah/Total & & & \\
\hline
\end{tabular}


sumberdaya fisik yang memiliki peran vital dalam usaha budi daya rumput laut. Ketersediaan lahan yang layak akan menjamin produksi rumput laut secara berkesinambungan. Luas lahan eksisting dan jumlah unit usaha memiliki keterkaitan erat dimana pertambahan luas lahan (ekstensifikasi) akan terjadi bilamana unit usaha bertambah, baik pertambahan jumlah pembudidaya ataupun terjadi pertambahan input produksi khususnya tali bentangan dalam suatu unit usaha.

\section{Kelayakan Lahan Eksisting dan Potensi Pengembangan}

Berdasarkan hasil-hasil penelitian sebelumnya di lokasi Teluk Kotania, parameter kualitas air bagi peruntukan budi daya rumput laut (2008 - 2010) meliputi kedalaman, kecerahan, suhu, salinitas, oksigen terlarut (Laitupa, 2009; Direktorat Tata Ruang KKP, 2010), arus (Papalia 2008 dalam Laitupa, 2009) dan $\mathrm{pH}, \mathrm{NO}_{3}$ dan $\mathrm{PO}_{4}$ (Direktorat Tata Ruang KKP, 2010). Disimpulkan bahwa perairan Teluk Kotania terutama pada lokasi dimana usaha budi daya rumput laut saat ini sedang eksis dinyatakan layak bagi kegiatan budi daya rumput laut.

Pengamatan di lapangan menunjukkan adanya ancaman sedimentasi di wilayah Teluk Kotania dimana terlihat secara fisik bahwa sesaat setelah hujan turun maka perairan terlihat keruh. Hal ini diduga kuat terkait dengan maraknya penebangan pohon mangrove di Teluk Kotania untuk berbagai keperluan sehingga sedimen yang dibawa oleh aliran air pada saat hujan akan langsung masuk kedalam perairan laut karena semakin jarangnya tegakan mangrove yang berperan sebagai perangkap sedimen (sediment trap). Hal ini menunjukkan pentingnya upaya pengelolaan wilayah pesisir Teluk Kotania secara terpadu sehingga semua kepentingan baik di darat maupun di laut bisa terakomodasi secara harmonis.

Berdasarkan hasil analisis Laitupa (2009), diketahui bahwa kawasaan pesisir Teluk Kotania sangat sesuai (higly suitable) kelas S1 untuk kegiatan budi daya rumput laut dengan memperoleh nilai 80. Khusus untuk Dusun Wael, Balai Budi daya Laut Ambon memberikan skor penilaian 94 (Balai Budi daya Laut Ambon, 2010). Luas perairan Teluk Kotania secara keseluruhan adalah 7.568,51 $\mathrm{Ha}$ dengan potensi lahan pengembangan budi daya rumput laut diperkirakan mencapai $1.605,74$ Ha (Laitupa, 2009). Menurut Puja et al. (2001) lokasi yang cocok bagi pengembangan budi daya rumput laut adalah lokasi teluk yang didepannya terdapat pulau, dimana Teluk Kotania berhadapan langsung dengan Pulau Buano. Hal ini penting untuk menghindari kerusakan fisik rumput laut dari terpaan angin dan gelombang yang kuat.

Direktorat Tata Ruang KKP (2010), dalam rangka persiapan program Minapolitan di Kabupaten SBB memetakan lokasi kesesuaian budi daya rumput laut di Teluk Kotania diperoleh luas lahan (sangat sesuai) untuk kegiatan budi daya rumput laut atau areal budi daya seluas $6.025,85 \mathrm{Ha}$. Hasil ini berbeda dengan hasil yang diperoleh Laitupa (2009) seluas $1605,74 \mathrm{Ha}$ atau hasil perkiraan Bappeda Kabupaten SBB (2011) seluas $2500 \mathrm{Ha}$. Perbedaan nilai ini diduga diakibatkan kegiatan sampling dilakukan pada periode waktu (bulan) yang berbeda serta perbedaan jenis, kuantitas dan kisaran nilai parameter yang digunakan dalam menentukan tingkat kelayakan lahan.

Luas lahan yang dinyatakan sangat sesuai baik oleh Laitupa (2009) maupun Direktorat Tata Ruang KKP (2010) masih tersedia cukup luas dibandingkan dengan lahan eksisting di Teluk Kotania yang berdasarkan data lapangan tahun 2011 baru mencapai 138,62 Ha. Namun hasil wawancara dengan para pembudidaya khususnya di Teluk Kotania menunjukkan bahwa mereka kesulitan dalam mengatur tali bentangan yang dimiliki dikarenakan lahan yang terbatas. Berdasarkan pengamatan di lapangan kondisi ini terjadi karena sebagian besar pembudidaya masih berusaha untuk mencari lokasi yang dekat dari pantai dengan pertimbangan lebih mudah dan murah dalam pengontrolan usaha rumput laut.

Hasil wawancara dengan para pembudidaya menunjukkan sampai saat ini belum ada ketentuan tertulis menyangkut aturan kepemilikan lahan. Aturan tidak tertulis yang ada hanya berupa aturan bahwa bila seorang pembudidaya sudah menanam di suatu lokasi maka pembudidaya yang lain harus mencari lokasi lainnya yang masih kosong atau pembudidaya meminjam lahan yang sedang tidak dioperasikan oleh pembudidaya yang memiliki lahan tersebut.

Lokasi Nuruwe meskipun terdapat kegiatan usaha budi daya rumput laut namun tidak direkomendasikan (tanda panah warna merah) berdasarkan RTRW Kabupaten SBB sebab perairan Nuruwe termasuk perairan oseanis yang relatif lebih terbuka terhadap terjangan ombak dan gelombang terutama pada Musim Barat (Diskanlut Provinsi Maluku - Lemlit UNPATTI, 2005). 
Implikasi langsung dari kondisi ini terlihat dari kenyataan bahwa dalam setahun periode tanam efektif di Nuruwe hanya pada Musim Barat sebanyak 1 kali periode produksi dan Musim Timur sebanyak 2 kali periode produksi. Lokasi perairan Dusun Loun yang berada pada Teluk Nanusa dianggap kurang sesuai.

Pada tingkat Kabupaten SBB, Diskanlut Provinsi Maluku - Lemlit UNPATTI (2005) telah mengidentifikasi lokasi-lokasi yang dianggap layak bagi pengembangan budi daya termasuk budi daya rumput laut berdasarkan kondisi hidro oseanografis dalam kaitannya dengan penyusunan RTRW (Rencana Tata Ruang Laut Wilayah) Kabupaten SBB seperti pada Gambar 1. Berdasarkan Gambar 1 terlihat bahwa pada lokasi eksisting Teluk Kotania (Pulau Osi, Kotania, Wael, Airpesi, Taman Jaya) merupakan lokasi pengembangan yang direkomendasikan (tanda panah warna coklat).

Lokasi-lokasi potensial budi daya rumput laut lainnya berdasarkan kondisi-hidro oseanografis di Kabupaten SBB hingga penelitian ini dilakukan yang belum dikembangkan adalah masing-masing sebelah utara Pulau Manipa, Kelang dan Buano serta Dusun Rumahkay. Hal ini menunjukkan bahwa selain masih banyaknya potensi lahan yang belum termanfaatkan di wilayah Teluk Kotania, juga tersedia lahan pada lokasi-lokasi lain yang belum dikelola bagi pengembangan usaha rumput laut sehingga secara umum ketersediaan lahan bagi usaha budi daya rumput di Kabupaten SBB tersedia dalam jumlah yang sangat memadai.

\section{b. Sarana}

Sarana produksi yang berperan dalam usaha budi daya rumput laut meliputi material dan sarana penunjang serta bibit.

\section{Material dan Sarana Penunjang}

Komponen material yang dipakai oleh para pembudidaya di Kabupaten SBB menyesuaikan dengan metode budi daya yang digunakan yakni metode long line atau rawai. Metode long line yang diterapkan biasanya berupa tali bentangan yang dirangkai berbentuk segi empat dengan menggunakan tali utama. Material utama dan sarana penunjang yang digunakan oleh para pembudidaya tertera pada Tabel 3. Material utama dan sarana penunjang di lokasi budi daya cukup mudah diperoleh karena sebagian sudah tersedia dan sebagian lainnya dijual di Kota Piru yang tidak jauh dari Teluk Kotania maupun Nuruwe.

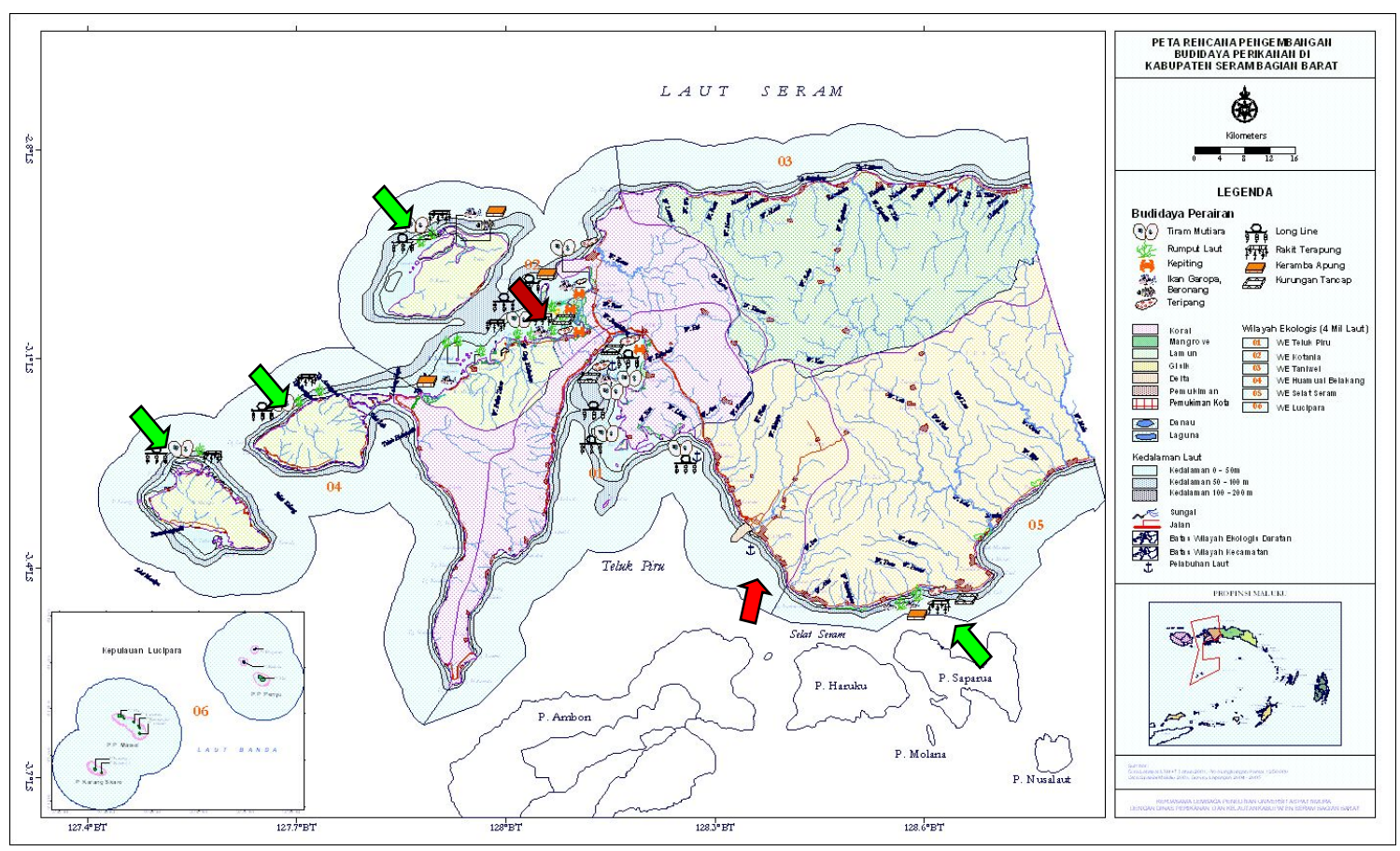

Sumber: RTRW Kabupaten Seram Bagian Barat, Dinas Perikanan Laut Provinsi Maluku - Lembaga Penelitian UNPATTI (2005)// Source: Spatial Plans of the Western Seram District, Marine Fisheriy Services of . Maluku Province-UNPATTI Research Unit (2005)

\section{Gambar 1. Rencana Tata Ruang Laut Wilayah Kabupaten Seram Bagian Barat.}

Figure 1. Western Seram Regency Marine Spatial Planning.

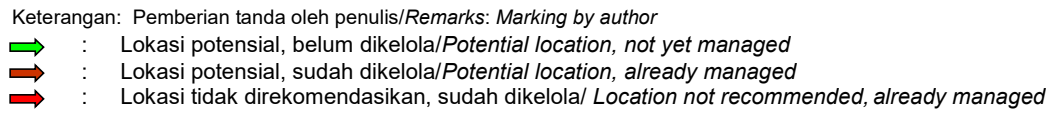


Tabel 3. Komponen Material/Sarana Penunjang Usaha Budidaya Rumput Kotoni Laut di Kabupaten Seram Bagian Barat serta Spesifikasi dan Kegunaannya.

Table 3. Component Of Materials /Supporting Facilities For Cottoni Seaweed Cultivation In Western Seram Regency, Specification And Its Utility.

\begin{tabular}{|c|c|c|}
\hline $\begin{array}{l}\text { Komponen Material \& } \\
\text { Sarana Penunjang/Component of } \\
\text { Materials \& Supporting Facilities }\end{array}$ & Spesifikasi/Specification & Kegunaaan/Utility \\
\hline \multicolumn{3}{|l|}{ Material Utama/ Main Material: } \\
\hline Tali PE (tali jangkar/line anchor) & $\varnothing 8 ; 10$ atau 12 mm & Mengikat jangkar/ Tie anchor \\
\hline Tali PE (tali utama/ line primary) & $\varnothing$ 6; 8; atau $10 \mathrm{~mm}$ & $\begin{array}{l}\text { Mengikat tali bentangan/ Tie a } \\
\text { stretch rope }\end{array}$ \\
\hline Tali PE (tali bentangan/line expanse) & $\varnothing 4$ atau $5 \mathrm{~mm}$ & Menggantung bibit/ Hanging seeds \\
\hline Tali PE (tali bibit/line seed) & $\varnothing 1$ atau $2 \mathrm{~mm}$ & $\begin{array}{l}\text { Mengikat bibit pada tali bentangan/ } \\
\text { Tie the seeds to the stretch rope }\end{array}$ \\
\hline Jangkar/ Anchor & $\begin{array}{l}\text { Cor beton; tiang tancap atau karang } \\
\text { mati/Cast concrete; pole or dead coral }\end{array}$ & $\begin{array}{l}\text { Menahan konstruksi long line/ Hold } \\
\text { long line construction }\end{array}$ \\
\hline Pelampung Utama/ Main buoy & Styroafoam $\varnothing 25 \mathrm{~cm}$ & Memberi daya apung/ Give buoying \\
\hline $\begin{array}{l}\text { Pelampung Botol Bekas Air Mineral/ } \\
\text { Floating Used Mineral Water Bottles }\end{array}$ & $\begin{array}{l}\text { Botol plastik } 600 \text { atau } 1500 \mathrm{ml} / \\
600 \text { or } 1500 \mathrm{ml} \text { plastic bottle }\end{array}$ & Memberi daya apung/ Give buoying \\
\hline \multicolumn{3}{|l|}{$\begin{array}{l}\text { Sarana Penunjang/ Supporting } \\
\text { Facilities: }\end{array}$} \\
\hline Sampan & Kayu/Wood & $\begin{array}{l}\text { Monitoring dan perawatan } \\
\text { usaha budidaya/ Monitoring and } \\
\text { maintenance of cultivation business }\end{array}$ \\
\hline Ketinting & Mesin 2,5 PK/ 2.5 PK machine & $\begin{array}{l}\text { Monitoring dan perawatan } \\
\text { usaha budidaya/ Monitoring and } \\
\text { maintenance of cultivation business }\end{array}$ \\
\hline Terpal & Plastik/ Plastic & $\begin{array}{l}\text { Sarana pasca panen/ Post-harvest } \\
\text { facilities }\end{array}$ \\
\hline Waring & Nilon/ Nylon & $\begin{array}{l}\text { Sarana pasca panen/ Post-harvest } \\
\text { facilities }\end{array}$ \\
\hline Para-Para & Kayu atau bambu/ Wood or bamboo & $\begin{array}{l}\text { Sarana pasca panen (tempat } \\
\text { penjemuran)/ Post-harvest facilities } \\
\text { (drying place) }\end{array}$ \\
\hline
\end{tabular}

Material lainnya seperti karung, tali rafia digunakan dalam jumlah terbatas sebab digunakan hanya pada saat pasca panen. Sebagian besar pembeli bahkan sudah menyiapkan karung pada saat akan melakukan pembelian rumput laut kering.

Secara umum material yang digunakan pada semua lokasi penelitian umumnya sama. Namun demikian terdapat perbedaan-perbedaan tertentu yang disesuaikan dengan kebiasaan pembudidaya dan ketersediaan material di lokasi tersebut. Sebagai contoh pembudidaya di Pulau Osi sebagian menggunakan pelampung gabus untuk menambah daya apung terutama pada saat umur rumput laut memasuki umur 4 minggu. Hal ini tidak dijumpai di lokasi lain dan berdasarkan wawancara dengan pembudidaya bahwa hal ini ditempuh karena pada lokasi tersebut biasanya agak kesulitan untuk mendapatkan pelampung botol air mineral. Disamping itu untuk pengikatan bibit biasanya digunakan tali
PE $\varnothing 1$ atau $2 \mathrm{~mm}$, pada lokasi-lokasi lainnya yang berada di Teluk Kotania sebagian besar pembudidaya menggunakan tali bibit yang diurai dari potongan tali PE berukuran besar ( $\geq \varnothing 4 \mathrm{~mm}$ ). Pada lokasi budi daya di Loun pembudidaya selain menggunakan tali PE sebagai tali bibit juga menggunakan tali rafia.

Dari segi pemasangan tali bentangan, pada sebagian besar lokasi jarak antar tali bentangan pembudidaya responden adalah 1,5 meter atau dimodifikasi menjadi 1 meter pada Musim Timur dan 2 meter pada Musim Barat. Hal ini menurut pembudidaya dimaksudkan untuk menghemat penggunaan lahan budi daya. Sedangkan pada lokasi Nuruwe, jarak antar tali bentangan berjarak 5 meter. Hal ini terkait dengan masih kurangnya pembudidaya pada lokasi tersebut sehingga masih tersedia ruang yang cukup untuk pemasangan long line. 
Operasional pemanfaatan tali bentangan (tali PE Ø 4 atau $5 \mathrm{~mm}$ ) dilapangan pada sebagian besar lokasi dikondisikan dengan ketersediaan lahan sehingga tali bentangan 1 bal ada yang dibagi manjadi dua masing-masing 50 meter dan sebagian kecil lainnya bahkan membagi menjadi 4 bagian masing-masing sepanjang 25 meter.

Jumlah dan prosentase kepemilikan tali bentangan responden pembudidaya rumput laut tersaji pada Gambar 2. Gambar 2 menunjukkan bahwa mayoritas pembudidaya di Kabupaten SBB memiliki tali bentangan yang berkisar antara: 20 - 29 dan 30 - 39 bal. Kepemilikian tali ini akan berpengaruh terhadap luas lahan yang dipergunakan dalam usaha budi daya sekaligus berpengaruh terhadap volume produksi rumput yang dihasilkan.

\section{Bibit}

Bibit rumput laut yang saat ini digunakan oleh pembudidaya di Kabupaten SBB, menurut responden Bapak $\mathrm{H}$. Ibrahim, kepala dusun dan sesepu masyarakat di Pulau Osi pada mulanya berasal dari Taliabu, Maluku Utara yang dibawa oleh para pelaut pada tahun 1990-an. Namun karena saat itu tidak ada pembeli rumput laut sehingga usaha yang diujicoba masyarakat di pulau Osi saat itu tidak berkembang. Usaha budi daya kembali dilanjutkan kembali pada tahun 2005 pada saat pemintaan rumput laut meningkat. Bibit dari Pulau Osi selanjutnya menyebar ke dusun-dusun lainnya di Teluk Kotania. Metode penyediaan bibit yang dilakukan pembudidaya di Kabupaten SBB adalah melalui metode reproduksi vegetatif yakni perbanyakan batang atau stek (Atmadja, 2007) atau istilah lain fragmentasi (Aslan, 1998).
Produksi bibit rumput laut yang dihasilkan oleh pembudidaya di Kabupaten SBB kususnya pada lokasi-lokasi budi daya di Teluk Kotania selain untuk memenuhi kebutuhan sendiri juga biasanya dijual ke lokasi lainnya yang tidak dapat melakukan kegiatan budi daya sepanjang tahun seperti Loun dan Nuruwe serta kadang-kadang untuk memenuhi permintaan dari luar daerah lain seperti ke Maluku Tengah dan Maluku Tenggara. Keberhasilan suatu usaha budi daya rumput laut sangat tergantung pada bibit yang tersedia. Menurut Indriani dan Sumiarsih (2003) ciri-ciri bibit yang baik adalah apabila dipegang terasa elastis, mempunyai cabang yang banyak, ujungnya berwarna kuning kemerahmerahan, batang tebal dan bebas dari tanaman yang lain. Disamping itu umur bibit sebaiknya 25 - 35 hari (Direktorat Jenderal Perikanan Budi daya, 2005).

Kualitas bibit sangat menentukan produktivitas, kualitas produk dan ketahanan terhadap penyakit. Penggunaan bibit unggul merupakan cara yang sangat penting untuk pengendalian penyakit ice-ice (Direktorat Kesling DKP, 2005). Lebih lanjut Baedah (2011) menyatakan salah satu kendala pengembangan budi daya rumput laut adalah kualitas bibit rumput laut yang masih rendah seperti pertumbuhan kerdil/ lambat/tidak maksimal, mudah terserang hama dan penyakit, mudah tertutupi lumut, tidak tahan terhadap stressor lingkungan serta belum adanya tahapan/proses produksi bibit yang baku. Berkaitan dengan hal tersebut, kedepan dipandang perlu adanya suatu kebun bibit ideal (terstandarisasi) bagi pembudidaya di Kabupaten SBB. Kebun bibit dimaksud selain untuk menjamin ketersediaan bibit juga untuk mengeliminir terjadinya gagal produksi akibat serangan penyakit yang diakibatkan oleh penggunaan bibit yang tidak berkualitas.

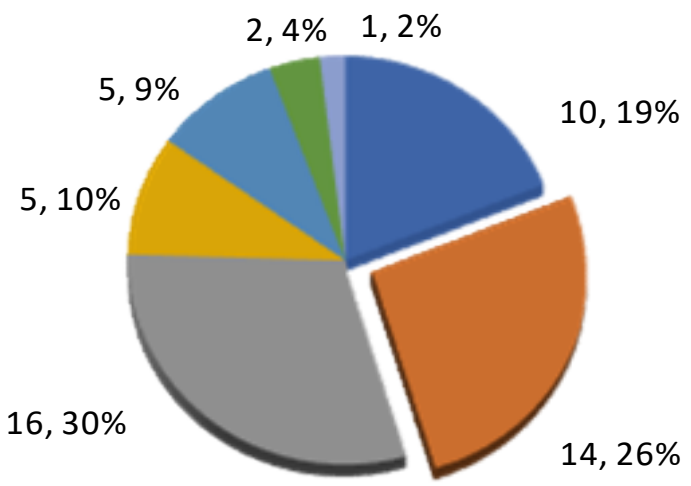

$$
\begin{aligned}
& 10 \text { - } 19 \mathrm{Bal} \\
& 20 \text { - } 29 \mathrm{Bal} \\
& 30 \text { - } 39 \mathrm{Bal} \\
& 40-49 \mathrm{Bal} \\
& 50 \text { - } 59 \mathrm{Bal} \\
& 60 \text { - } 69 \mathrm{Bal} \\
& 70-79 \mathrm{Bal}
\end{aligned}
$$

\section{Gambar 2. Jumlah dan Prosentase Kepemilikan Tali Bentangan Pembudidaya Rumput Laut Kotoni.} Figure 2. Amount And Percentage Of Long Line Ownership Of Cottoni Seaweed Farmers. 


\section{c. Tenaga Kerja}

Berdasarkan hasil wawancara dan pengamatan di lapangan diketahui bahwa jumlah tenaga kerja yang digunakan sepanjang tahun berbeda tergantung musim. Pada musim Barat dimana produksi cenderung menurun pembudidaya memakai tenaga kerja dalam keluarga sendiri yakni istri dan anak-anak.

Pada musim Timur dimana aktifitas dan produksi cenderung meningkat pembudidaya biasanya menambah tenaga kerja dari luar terutama untuk pengikatan tali bibit yang dihargai antara Rp5.000 - Rp8.000 per satu tali bentangan dan pengangkutan bibit berkisar antara Rp50.000 - Rp 100.000 per hari, biaya panen dihargai Rp50.000,- per hari. Hal ini menunjukkan bahwa tenaga kerja tambahan yang dipakai pembudidaya hanya bersifat temporer untuk kegiatan-kegiatan tertentu.

Pembudidaya yang berada pada lokasilokasi budi daya di Teluk Kotania dan Dusun Loun berasal dari Suku Buton sedangkan di Negeri Nuruwe berasal dari penduduk lokal Maluku. Adapun jumlah tenaga kerja yang terlibat dalam satu unit usaha budi daya rumput laut pada kegiatan pengikatan bibit menyerap sekitar 4 orang sedangkan pada kegiatan penanaman, pemeliharaan dan panen umumnya berjumlah 2 orang.

Sebagian besar pembudidaya di Kabupaten SBB mempunyai mata pencaharian lain selain usaha budi daya rumput laut. Pada lokasi yang terletak di wilayah Teluk Kotania (Pulau Osi, Kotania,
Wael, Airpesi dan Taman Jaya), selain berusaha sebagai pembudidaya rumput laut juga memiliki alternatif pekerjaan lain seperti: berkebun, usaha minyak kayu putih dan usaha kopra. Demikian juga halnya di Dusun Loun, pembudidaya memiliki alternatif pekerjaan yaitu berkebun. Sedangkan di Nuruwe sebagian pembudidaya berprofesi sebagai pencari damar. Hal ini berimplikasi pada naik turunnya jumlah pembudidaya dan besar kecilnya luas lahan yang dikelola oleh pembudidaya.

Tenaga kerja adalah setiap orang yang mampu melakukan pekerjaan guna menghasilkan barang dan/atau jasa baik untuk memenuhi kebutuhan sendiri maupun untuk masyarakat (UU RI No. 13 tahun 2003). Tenaga kerja pembudidaya berdasarkan tingkatan umur, tingkat pendidikan, tanggungan keluarga dan pengalaman usaha dijelaskan sebagai berikut:

\section{Tingkatan Umur}

Berdasarkan tabulasi hasil kuisioner, prosentase tingkatan umur pembudidaya di Kabupaten SBB disajikan pada Gambar 4. Gambar 4 menunjukkan bahwa prosentase pembudidaya rumput laut di Kabupaten SBB dengan kisaran umur $30-39$ tahun merupakan prosentase terbesar yakni $38 \%$, menyusul kisaran umur 40 - 49 tahun sebesar $31 \%$ dan yang terkecil kisaran umur 20 - 29 tahun. Bila dikaitkan dengan defenisi BPS berdasarkan PTKD (Perencanaan Tenaga Kerja Daerah) maka semua kisaran umur yang ada merujuk kepada usia kerja, dan angkatan kerja karena berumur lebih dari 15 tahun (BPS Provinsi Maluku, 2010).

\section{Tingkatan Umur/ Level of Age}

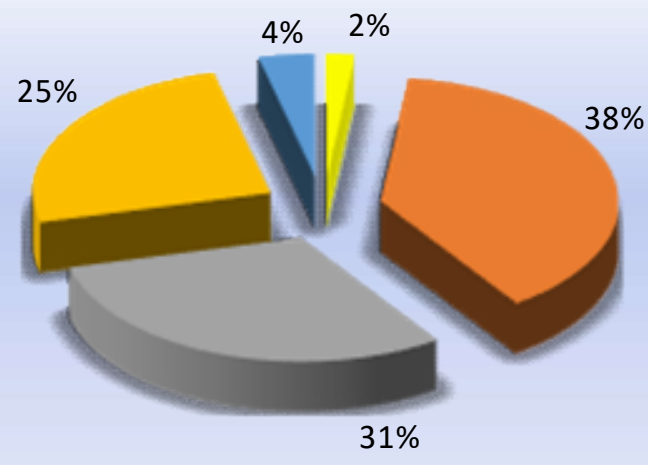

20 - 29 tahun

30 - 39 tahun

40 - 49 tahun

50 - 59 tahun

- 60 - 70 tahun

Gambar 4. Prosentase Tingkatan Umur Responden Pembudidaya. Figure 4. Percentage Of Age Level Of Farmers' Respondent. 
Hasil tabulasi data responden pembudidaya menunjukkan bahwa umur termuda responden pembudidaya ditemukan di Dusun Airpesi yakni 27 tahun dan tertua di Dusun Loun yakni 64 tahun. Rata-rata umur pembudidaya terendah di Negeri Nuruwe yakni 40,3 tahun dan yang tertinggi di Dusun Kotania yakni 40,6 tahun dengan total rata-rata untuk semua lokasi sebesar 43,9 tahun. Secara umum umur pembudidaya rumput laut di Kabupaten SBB berada pada usia produktif menurut Soeharjo dan Patong (1984) yakni berada diantara 15 - 54 tahun.

Umur berkaitan dengan pengalaman belajar, kemampuan dan kematangan. Kematangan seseorang baik secara fisik maupun biologis dan mental dapat dilihat dari berbagai indikator. Umur merupakan salah satu faktor sosial yang berpengaruh terhadap aktifitas seseorang dalam kehidupan sehari-hari.

\section{Tingkat Pendidikan}

Berdasarkan tabulasi hasil kuisioner, prosentase tingkat pendidikan pembudidaya di Kabupaten SBB disajikan pada Gambar 5. Gambar 5 menunjukkan bahwa prosentase terbesar pembudidaya rumput laut di Kabupaten SBB berpendidikan SD (Sekolah Dasar)/Sederajat yakni sebesar $77 \%$ menyusul SMP (Sekolah Menengah Pertama)/Sederajat sebesar $15 \%$.

Hal ini menunjukkan bahwa dari segi pendidikan formal mayoritas pembudidaya di kabupaten SBB kualitas pendidikannya rendah. Pendidikan yang dianggap tinggi untuk produsen adalah adalah tamat SLTP dan SLTA. Pada tingkat pendidikan tersebut pembudidaya rumput laut diharapkan mampu menyerap berbagai informasi tentang kegiatan yang terkait dengan bidang usaha yang dikelola.

Pendidikan yang dialami seseorang menyebabkan individu banyak mendapatkan pengetahuan, pengalaman, dan sikap mental yang kuat. Pengetahuan, pengalaman dan sikap mental yang diperoleh akan berpengaruh terhadap pola tingkah laku dan sikapnya. Diasumsikan bahwa semakin tinggi tingkat pendidikan, semakin tinggi produktivitas tenaga kerja, semakin tinggi pula pengaruhnya terhadap pertumbuhan ekonomi suatu masyarakat sesuai dengan teori Human Capital bahwa pendidikan memiliki pengaruh terhadap pertumbuhan ekonomi dimana pendidikan berperan dalam meningkatkan produktivitas tenaga kerja (Ace dan Tilaar, 1993).

\section{Tanggungan Keluarga}

Pengelompokanjumlah tanggungan keluarga dilakukan berdasarkan klasifikasi dari BPS yakni tanggungan keluarga kecil $1-3$ orang, tanggungan keluarga sedang 4 - 6 orang dan tanggungan keluarga besar lebih dari 6 orang. Berdasarkan tabulasi hasil kuisioner, prosentase jumlah tanggungan keluarga responden pembudidaya di Kabupaten SBB disajikan pada Gambar 6. Gambar 6 menunjukkan bahwa prosentase terbesar sebanyak $59 \%$ responden pembudidaya di Kabupaten SBB memiliki tanggungan keluarga sebanyak 4-6 orang yang oleh BPS dikategorikan sebagai jumlah tanggungan sedang. Kemudian menyusul tanggungan 1-3 orang sebesar $32 \%$ yang dikategorikan jumlah tanggungan kecil dan terakhir tanggungan 7-9 orang sebesar $9 \%$.

\section{Tingkat Pendidikan/ Level of Education}

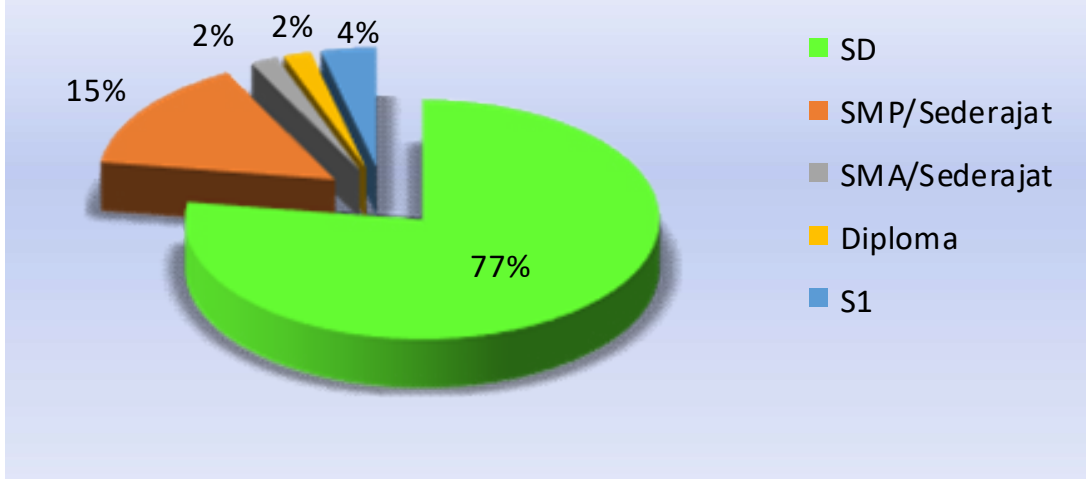

Gambar 5. Prosentase Tingkat Pendidikan Responden Pembudidaya.

Figure 5. Percentage Of Education Level Of Farmers' Respondent. 


\section{Tanggungan Keluarga/ Family Dependents}

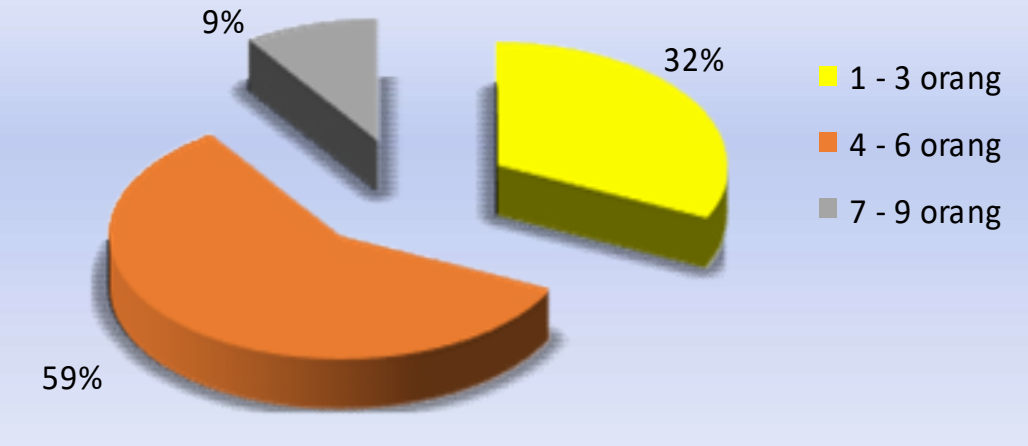

Gambar 6. Prosentase Tanggungan Keluarga Responden Pembudidaya.

Figure 6. Percentage Of Family Dependents Of Farmers' Respondent.

Tanggungan keluarga dapat diartikan sebagai sejumlah orang yang tinggal dalam satu rumah yang secara langsung menjadi beban atau tanggungan kepala keluarga ataupun yang tidak serumah namun masih menjadi tanggungan kepala keluarga.

\section{Pengalaman Usaha}

Berdasarkan tabulasi hasil kuisioner, prosentase pengalaman usaha responden pembudidaya di Kabupaten SBB disajikan pada Gambar 7. Gambar 7 menunjukkan bahwa prosentase terbesar pengalaman usaha responden pembudidaya di Kabupaten SBB adalah berada pada kisaran 5-6 tahun sebesar $24,45 \%$. Selanjutnya berturut-turut kisaran $3-4$ tahun dan 0-2 tahun masing-masing sebesar
$23,44 \%$ dan $6,11 \%$. Menurut Soeharjo dan Patong (1984), kategori kurang berpengalaman apabila petani (pembudidaya) menggeluti pekerjaannya kurang dari 5 tahun, cukup berpengalaman 5 10 tahun, dan berpengalaman di atas 10 tahun. Berdasarkan hal tersebut maka prosentase kisaran pengalaman usaha pembudidaya rumput laut di Kabupaten SBB dapat dikatakan mayoritas pembudidaya dikategorikan cukup berpengalaman.

Pengalaman usaha merupakan salah satu faktor yang menentukan dalam kegiatan budi daya rumput laut. Semakin lama pembudidaya menggeluti kegiatan budi daya rumput laut, semakin banyak pengetahuan dan keterampilan yang dimiliki, sehingga mampu mengelola usahanya secara efisien untuk meningkatkan produksi dan pendapatan.

\section{Pengalaman Usaha/ Business Experince}

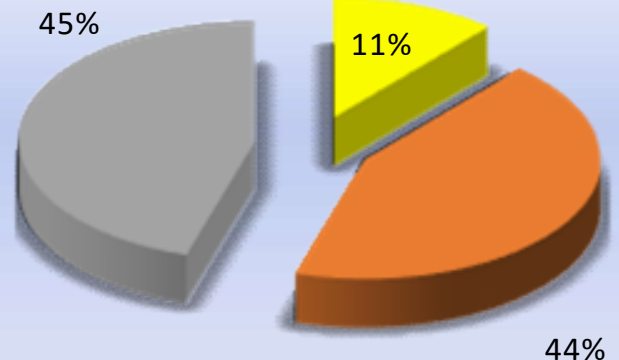

0 - 2 tahun

3 - 4 tahun

5 - 6 tahun

$44 \%$

Gambar 7. Prosentase Pengalaman Usaha Responden Pembudidaya. Figure 7. Percentage Of Business Experience Of Farmers' Respondent. 


\section{Perkembangan Produksi}

Produksi rumput laut di Kabupaten SBB sangat dipengaruhi oleh musim yakni Musim Barat dan Musim Timur. Pada musim Barat dimana kondisi perairan relatif tenang produksi biasanya menurun. Hal tersebut sejalan dengan pernyataan Soegiarto dkk., (1978 dalam Laitupa, 2009) bahwa iklim, letak geografis dan faktor oseanografi sangat menentukan pertumbuhan rumput laut. Kondisi ini semakin diperparah oleh kenyataan bahwa harga rumput laut di tingkat pembudidaya pada Musim Barat selalu jatuh di bawah harga normal yang berakibat banyaknya pembudidaya yang menghentikan sementara operasional faktor-faktor produksi yang dimilikinya.

Kondisi yang sebaliknya terjadi pada musim Timur dimana produksi meningkat, harga jual yang baik sehingga terjadi perbedaan produktivitas yang nyata antara Musim Barat dan Musim Timur. Pola tersebut terjadi secara periodik setiap tahunnya sehingga pada Musim Barat pembudidaya cenderung memilih menghindari resiko (risk aversion). Kegiatan budi daya dilakukan hanya untuk mempertahankan kelangsungan bibit sedangkan aktifitas sehari-hari lebih banyak difokuskan di darat seperti berkebun, mengolah minyak kayu putih atau mencari damar di hutan (Maryunus, 2012).

Pada lokasi budi daya di Teluk Kotania rata-rata panen biasanya berlangsung 5 sampai
6 kali dalam setahun. Beberapa pembudidaya yang menerapkan metode panen sebagian bisa mencapai 7 - 8 kali panen. Sedangkan pada lokasi Loun dan Nuruwe hanya berlangsung hanya 3 kali dalam setahun.

\section{a. Perkembangan Volume Produksi}

Perkembangan volume produksi rumput laut kering di Kabupaten SBB selama periode tahun 2006 sampai dengan tahun 2010 disajikan pada Tabel 4. Tabel 4 menunjukkan bahwa pada lokasi-lokasi budi daya di Teluk Kotania terjadi peningkatan produksi dari tahun 2006 sampai tahun 2008. Peningkatan produksi ini disebabkan karena dalam kurun waktu tersebut rumput laut dari Kabupaten SBB sudah mulai dikenal oleh pembeli dari luar daerah serta kecenderungan naiknya harga rumput laut yang mendorong sebagian besar masyarakat pesisir Teluk Kotania beralih profesi menjadi pembudidaya rumput laut.

Hal ini turut didukung oleh kebijakan pemerintah saat itu yakni pemberian paket bantuan sarana budi daya baik dari Dinas Kelautan dan Perikanan Provinsi Maluku maupun dari Dinas Kelautan dan Perikanan Kabupaten SBB.

Pada tahun 2006 dan 2007 lokasi Pulau Osi merupakan produsen terbesar di Kabupaten SBB total masing-masing dengan total produksi 576 ton dan 1.152 ton. Hal ini disebabkan Pulau Osi merupakan lokasi awal pengembangan budi

Tabel 4. Perkembangan Volume Produksi Rumput Laut Kotoni Kering di Lokasi Eksisting Kabupaten Seram Bagian Barat, 2006 - 2010.

Table 4. Development Of Dried Cottoni Seaweed Production Volume In Existing Location of Western Seram Regency, 2006 - 2010.

\begin{tabular}{|c|c|c|c|c|c|c|}
\hline Lokasi/Location & 2006 & 2007 & 2008 & 2009 & 2010 & $\begin{array}{l}\text { Jumlah Total/ } \\
\text { Total Amount (Ton) }\end{array}$ \\
\hline \multicolumn{7}{|l|}{ Desa Eti/Eti Village } \\
\hline Pulau Osi & 576.0 & $1,152.0$ & $1,296.0$ & 655.2 & 460.0 & $4,139.2$ \\
\hline Kotania & 432.0 & 936.0 & $1,224.0$ & 604.8 & 453.6 & $3,650.4$ \\
\hline Loun & 2.6 & - & 19.2 & 16.0 & 12.0 & 49.8 \\
\hline \multicolumn{7}{|c|}{ Desa Piru/Piru Village } \\
\hline Wael & 504.0 & $1,080.0$ & $1,584.0$ & $1,015.2$ & 950.4 & $5,133.6$ \\
\hline Airpesi & 432.0 & 864.0 & $1,080.0$ & 496.4 & 108.0 & $2,980.4$ \\
\hline Taman Jaya & 432.0 & 792.0 & $1,080.0$ & 385.0 & 108.0 & $2,797.0$ \\
\hline \multicolumn{7}{|c|}{ Negeri Nuruwe/Nuruwe Village } \\
\hline Nuruwe & 24.0 & 24.0 & 50.4 & 96.0 & 68.0 & 262.4 \\
\hline Jumlah/Total & $2,402.6$ & $4,848.0$ & $6,333.6$ & $3,268.6$ & $2,160.0$ & $19,012.8$ \\
\hline
\end{tabular}

Sumber/ Source: Data Primer, Dinas Kelautan dan Perikanan Kab. SBB (2011)/

Source: Primary Data, Marine and Fisheries Agency of West Ceram District (2011) 
daya rumput laut di Kabupaten SBB. Sejak tahun 2008 yang merupakan puncak volume produksi di Kabupaten SBB, lokasi produsen terbesar beralih ke Dusun Wael. Hal ini diduga terkait faktor oseanografis dimana lokasi Dusun Pulau Osi relatif lebih terbuka dibanding dengan lokasi Dusun Wael yang lebih terlindung di dalam teluk.

Sejak tahun 2009 sampai dengan 2010 termasuk 2011 (Tabel 4) terjadi penurunan produksi. Hal ini merupakan akumulasi dari beberapa faktor yang secara garis besar dibagi atas dua yakni faktor dari dalam dan faktor dari luar. Faktor dari dalam yakni pertama, penurunan bobot biomassa produksi rumput laut. Hal ini didasarkan pada hasil wawancara dengan beberapa pembudidaya bahwa beberapa tahun sebelumnya produksi rumput laut kering dalam satu long line panjang 50 meter dapat mencapai 40 - $60 \mathrm{~kg}$ setelah itu hanya rata-rata berkisar antara $20-25 \mathrm{~kg}$. Penurunan ini diduga kuat karena menurunnya daya dukung lingkungan (carrying capacity) terutama akibat tata letak unit long line yang kebanyakan menumpuk hanya disekitar pantai dan terjadinya sedimentasi akibat pembabatan mangrove. Kedua menurunnya kualitas bibit yang digunakan secara berulang-ulang sehingga siklus hidup patogen penyebab penyakit ice-ice tidak bisa diputus dan ketiga semakin maraknya kegiatan destructive dan poisoning fishing yakni penggunaan potas dan bom yang berdampak buruk terhadap produksi rumput laut. Sedangkan faktor dari luar adalah ketidakstabilan harga terutama setelah harga puncak di tahun 2009. Hal ini secara psikologis menimbulkan demotivasi pada sebagian pembudidaya sehingga beberapa diantaranya beralih sementara ke pekerjaan di darat yang dianggap lebih memiliki kepastian hasil. Pada tahun 2012 sampai dengan 2015 pada lokasi-lokasi budi daya di Teluk Kotania terjadi kematian massal rumput laut yang diduga diakibatkan oleh adanya pencemaran dari limbah sagu dimana pabrik tersebut kemudian berhenti beroperasi. Saat ini usaha budi daya rumput laut di wilayah tersebut perlahan lahan kembali mulai berjalan meskipun dihadapkan pada kenyataan belum adanya pembeli rumput laut seperti sebelum terjadinya kematian massal.

Pada lokasi Loun, produksi tertinggi juga tercapai pada tahun 2008 sebesar 19,2 ton sedangkan terendah pada tahun 2006 sebesar 2,6 ton. Hal ini disebabkan karena pada tahun 2006, usaha budi daya rumput laut di loasi ini sifatnya masih coba-coba yang dirintis oleh Bapak La
Ode Mus. Sementara di Lokasi Nuruwe produksi tertinggi dicapai pada tahun 2009 sebesar 96 ton dan terendah pada tahun 2006 dan 2007 sebesar 24 ton. Sama seperti di Dusun Loun tahun 2006 usaha budi daya rumput laut di Nuruwe sifatnya masih coba-coba yang dirintis oleh dua orang sarjana yaitu Bapak Wiils A. Maail dan Ulis Hitipeuw.

\section{b. Diversifikasi dan Mutu Produk}

Hingga saat ini produksi dari hasil budi daya rumput laut di Kabupaten SBB masih berupa rumput laut kering (dried seaweed) yang berarti bahwa belum ada diversifikasi dari sisi produk. Hasil produksi budi daya yang hanya dijual dalam bentuk rumput laut kering juga mengindikasikan belum adanya nilai tambah bagi peningkatan ekonomi pembudidaya maupun peningkatan ekonomi daerah. Hal ini sejalan dengan fakta yang dikemukakan oleh Bank Indonesia (2008), bahwa perkembangan industri rumput laut di Indonesia cukup menggembirakan, tetapi produknya masih terbatas pada produk dasar (base products), bukan merupakan end products yang langsung dapat digunakan industri pengguna. Diversifikasi dan mutu produk menunjukkan tingkat daya saing suatu produk. Diversifikasi akan meningkatkan nilai tambah (value added), sedangkan mutu yang baik atau memenuhi standar akan membentuk daya saing yang kuat (Maryunus, 2012).

Kualitas atau mutu rumput laut Kabupaten SBB berdasarkan laporan Bappeda Kab. SBB memiliki rendemen karaginan sebesar $73,36 \%$, lebih tinggi dari Pulau Jawa $(65,75 \%)$ dan Tual $(34,48 \%)$ dengan kadar air 10,18-11,29\% dan bau spesifik rumput laut maka kualitasnya memenuhi standar ekspor (Bappeda Kab. SBB, 2011). Hal tersebut mengindikasikan bahwa kualitas rumput laut kering yang berasal dari Kabupaten SBB berpotensi untuk menjadi salah satu produsen rumput laut dengan kualitas terbaik dan berdaya saing tinggi di Indonesia.

Hasil wawancara dengan pedagang pengumpul diketahui bahwa bahwa harga pasaran rumput laut dari Kabupaten SBB oleh eksportir atau industri pengolah di Surabaya dihargai sama dengan rumput laut yang berasal dari daerah lain. Menurut Zulham dkk., (2007) pada pasar domestik tidak ada standar mutu perdagangan rumput laut kering. Dipasaran terdapat rumput laut kering mutu Gorontalo, Takalar, Sumenep dan lain-lain. Variasi mutu ini menyulitkan industri pengolahan lokal, 
karena biaya pengolahannya semakin meningkat. Pada tingkat pedagang besar mutu rumput laut kering ditentukan secara visual dengan kandungan kadar air $35-37 \%$.

Berdasarkan hasil wawancara dengan pedagang pengumpul di Kota Ambon, faktor kualitas masih menjadi salah satu masalah bagi pengembangan rumput laut di Kabupaten SBB. Hal ini bisa dilihat dari masih tingginya kadar air dari rumput laut yang dijual oleh para pembudidaya. Hal lainnya adalah rumput laut kering masih banyak tercampur dengan kotoran dan benda-benda asing. Beberapa pembudidaya bahkan diketahui melakukan tindakan curang yakni dengan sengaja membiarkan garam tetap menempel pada rumput laut kering, mencampur rumput laut dengan tumbuhan lain yang tampilan fisiknya menyerupai rumput laut kering atau menambahkan paku untuk menambah berat pada saat penimbangan. Kondisi demikian pada pihak lain sangat merugikan pedagang karena dari hasil wawancara diketahui bahwa setelah rumput laut tiba di Ambon sampai dengan kondisi siap diantarpulaukan mengalami susut hingga 20 persen.

Dinas Kelautan dan Perikanan Kabupaten SBB telah beberapa kali memberikan pelatihan pengolahan rumput laut untuk beberapa jenis olahan seperti: sirup rumput laut, dodol rumput laut dan permen rumput laut. Namun belum adanya segmen pasar yang jelas mengakibatkan olahan tersebut masih terbatas untuk konsumsi sendiri. Pada awal tahun 2011 Bank Indonesia Cabang Ambon bekerjasama dengan Staf Pengajar dari Fakultas Perikanan dan IImu Kelautan UNPATTI memberikan pelatihan pembuatan chip skala ramah tangga di Dusun Wael. Berdasarkan wawancara dengan Staf dari Bank Indonesia cabang Ambon, hal ini selain dimaksudkan untuk menciptakan nilai tambah produk juga dimaksudkan sebagai solusi sementara pengolahan rumput laut sebelum berdirinya pabrik pengolahan.

Pada level nasional adanya rencana kebijakan hilirisasi rumput laut (Kemenperin, 2017) dan klasterisasi rumput laut (Bappeda Kabupaten SBB, 2011; Pemrov Maluku 2010; Dir Tata Ruang KKP, 2010) merupakan peluang bagi penciptaan nilai tambah yang akan memberikan dampak ekonomi positif bagi pembudidaya maupun bagi perekonomian regional SBB dan Maluku.

\section{KESIMPULAN DAN IMPLIKASI KEBIJAKAN}

\section{Kesimpulan}

Secara umum faktor-faktor produksi usaha budi daya rumput laut di Kabupaten Seram Bagian Barat berada pada yang layak dan mendukung pengembangan usaha budi daya rumput laut. Pemanfaatan lahan yang layak bagi pengembangan usaha budi daya tingkat pemanfaatannya masih sangat kecil selain disebabkan belum terkelolanya lokasi-lokasi potensial juga disebabkan pemanfaatan lahan yang masih terfokus di sepanjang garis pantai. Material dan sarana penunjang, termasuk bibit cukup tersedia dan mudah didapatkan selain itu ada bantuan paket budi daya baik dari Pemerintah Kabupaten maupun Pemerintah Provinsi. Sedangkan dari segi aspek sumberdaya manusia pembudidaya, tingkat pendidikan yang didominasi sekolah dasar sedikit menyulitkan dalam transfer ilmu pengetahuan dan teknologi baru.

Secara akumulatif terjadi trend peningkatan produksi sejak tahun 2006 sampai dengan tahun 2008, selanjutnya menurun dari tahun 2008 hingga tahun 2010. Telah ada upaya diversifikasi produk namun belum memiliki segmen pasar. Mutu rumput laut kering yang diproduksi pembudidaya, secara umum belum sesuai dengan spesifikasi pabrikan dan eksportir.

\section{Implikasi Kebijakan}

Ketersediaan lahan yang layak dalam jumlah besar memberikan peluang bagi ekstensifikasi dalam rangka peningkatkan produksi dan pendapatan pembudidaya. Untuk mempermudah pengontrolan dan mengakses lahan potensial yang justru sebagian besar berada jauh dari garis pantai, dibutuhkan perhatian dan bantuan pemerintah berupa sarana transportasi perahu motor.

Dibutuhkan suatu upaya dengan melibatkan semua stake holder untuk mencegah terjadinya fluktuasi harga jual rumput laut karena hal tersebut akan berdampak langsung terhadap volume dan keberlanjutan suplai produksi rumput laut. Masih rendahnya kualitas produk rumput kering yang ada memerlukan suatu upaya pendampingan, pelatihan dan pembinaan yang intensif dari instansi terkait.

\section{UCAPAN TERIMA KASIH}

Ucapan terima kasih dan penghargaan disampaikan kepada Bapak Kepala Bidang Budi daya beserta Staf Dinas Kelautan dan Perikanan 
Kabupaten Seram Bagian Barat yang telah banyak membantu dan mendukung pelaksanaan kegiatan penelitian ini serta membantu penyediaan data-data terkait.

\section{DAFTAR PUSTAKA}

Ace, S dan H.A.R. Tilaar. 1993. Analisis Kebijakan Pendidikan: Studi Pengantar. PT Remaja Rosda Karya. Bandung

Arikunto, S. 2002. Prosedur Penelitian: Suatu Pendekatan Praktek. Penerbit Rineka Cipta, Jakarta

Aslan, L.M. 1998. Budi daya Rumput Laut. Penerbit Kanisius. Yogyakarta

Atmadja, W.S. 2007. Apa Itu Rumput Laut Sebenarnya?. http://www.coremap.or.id/print/article.php?id=264 (Diakses 12 Oktober 2017).

Baedah, M.A. 2011. Perlunya Standar Operasional Prosedur (SPO) Pengadaan Bibit Rumput Laut di Sulawesi Tengah. Makalah. Dinas Kelautan dan Perikanan Provinsi Sulawesi Tengah. Palu

Balai Budi Daya Laut Ambon. 2010. Laporan Tahunan Balai Budi daya Laut Ambon Tahun 2009. UPT Balai Budi daya Laut. Ambon

Bank Indonesia. 2008. Pengolahan Agar-Agar dan Manisan Rumput Laut. Direktorat Kredit, BPR dan UMKM. Bank Indonesia. Jakarta

Bappeda Kabupaten Seram Bagian Barat. 2011. Selayang Pandang Kabupaten Seram Bagian Barat Tahun 2010. Bappeda Kabupaten Seram Bagian Barat. Piru

Badan Pusat Statistik Provinsi Maluku. 2010. Seram Bagian Barat dalam Angka 2009. Badan Pusat Statistik Provinsi Maluku. Ambon

Creswell, J.W. 1994. Research Design: Qualitative and Quantitative Approaches. Sage Publications Inc. California

Dinas Perikanan dan Kelautan Provinsi Maluku Lemlit UNPATTI. 2005. Rencana Tata Ruang Laut Pesisir dan Pulau Pulau Kecil Wilayah Kabupaten Seram Bagian Barat. Naskah Akademik. Dinas Perikanan dan Kelautan Provinsi Maluku bekerjsama dengan Lembaga Penelitian Universitas Pattimura. Ambon

Direktorat Jenderal Perikanan Budi Daya. 2005. Profil Rumput Laut Indonesia. Direktorat Jenderal Perikanan Budi daya. Departemen Kelautan dan Perikanan. Jakarta

Direktorat Kesling Departemen Kelautan Perikanan. 2005. Penyakit ice ice Pada Budi daya Rumput Laut. Petunjuk Pengendalian. Direktorat Kesehatan Ikan dan Lingkungan. DJPB. Departemen Kelautan dan Perikanan RI. Jakarta
Direktorat Tata Ruang Kementerian Kelautan Perikanan. 2010. Bantuan Teknis Penyusunan Rencana Zonasi Rinci Kawasan Minapolitan di Kabupaten Seram Bagian Barat. Direktorat Tata Ruang Laut Pesisir dan Pulau-Pulau Kecil. DJP3K. Kementerian Kelautan dan Perikanan RI. Jakarta

Indriani, H. dan E. Suminarsih. 2003. Budi daya, Pengolahan dan Pemasaran Rumput Laut. PT Penebar Swadaya. Jakarta

Kementerian Perindustrian. 2017. Hilirisasi Rumput Laut Pacu Daya Saing dan Ekspor. http://www. kemenperin.go.id/artikel/15493/Hilirisasi-Rumput-Laut-Pacu-Produksi-dan-Ekspor (Diakses 14 Oktober 2017)

Laitupa, O.P. 2009. Strategi Pengembangan Budi daya Rumput Laut (Eucheuma cottonii) di Teluk Kotania Kabupaten Seram Bagian Barat. Tesis. Program Pascasarjana Universitas Pattimura. Program Studi IImu Kelautan. Ambon

Maryunus, R.P. 2012. Kajian Pengembangan Agribisnis Rumput Laut (Eucheuma cottonii) di Kabupaten Seram Bagian Barat. Tesis. Program Pascasarjana Universitas Pattimura. Program Studi IImu Kelautan. Ambon

Pemerintah Provinsi Maluku. 2010. Rencana Pengembangan Klaster Rumput Laut di Provinsi Maluku. Pemerintah Provinsi Maluku. Ambon

Peraturan Menteri Kelautan dan Perikanan RI Nomor Per.05/MEN/2009 Tentang Skala Usaha di Bidang Pembudidayaan Ikan.

Puja, Y., Sudjiharmo dan T. W. Aditya. 2001. Teknologi Budi daya Rumput Laut (Kappaphycus alvarezii). UPT Balai Budi daya Laut Lampung. DJPB. Departemen Kelautan dan Perikanan. Jakarta

Sugiyono. 2009. Metode Penelitian Kuantitatif dan Kualitatif. CV Alfabeta. Bandung

Soeharjo, A dan D. Patong. 1984. Sendi - Sendi Pokok Ilmu Usaha Tani. Lembaga Penerbitan Universitas Hasanuddin. Ujung Pandang

Soekartawi. 2002. Agribisnis: Teori dan Aplikasinya. PT Raja Grafindo Persada. Jakarta

Undang-Undang Republik Indonesia Nomor 3 Tahun 2003 Tentang Ketenagakerjaan

Wikipedia. 2011. Faktor Produksi. http://id.wikipedia. org/wiki/Faktor_produksi. (Diakses tanggal 11 Oktober 2017)

Zulham, A., A. H. Purnomo., T. Apriliani dan Y. Hikmayani. 2007. Assestment Klaster Perikanan: Studi Pengembangan Klaster Rumput Laut Kabupaten Sumenep. J. Bijak dan Riset Sosek KP. Vol 2 (2): 177-193 